\title{
Occurrence of acid erosion of the teeth, actinomycosis and polioencephalomalacia in flock of sheep fed wet low pectin citrus pulp
}

\section{Ocorrência de erosão ácida dos dentes, actinomicose e polioencefalomalacia em rebanho de ovinos alimentados com polpa cítrica úmida despectinada}

\author{
Vinícius José Moreira Nogueira', Priscila dos Santos Silva², Renan Braga Paiano', \\ Camila Raineri ${ }^{3}$, Daniela Becker Birgel ${ }^{2}$, Ricardo De Francisco Strefezzi², \\ Ricardo Luiz Moro de Sousa², Maria Cristina Ferrarini Nunes Soares Hage², \\ Eduardo Harry Birgel Junior ${ }^{2 *}$
}

\begin{abstract}
The citrus pulp can be used as a substitute in ruminant feed reducing costs and maintaining the nutritional quality of food. However, this compound should be used carefully so as not to cause harm to the animals. The present report aims to describe the occurrence of dental erosion, actinomycosis and polioencephalomalacia in sheep raised and kept with a wet low pectin citrus pulp based diet, composing 50\% of roughage. Actinomycosis was diagnosed in five animals through clinical and radiographic examinations and microbiological culture, and, after treatment, three animals were cured. Polioencephalomalacia was confirmed in ten animals by clinical diagnostics, in nine out of ten animals by therapeutic diagnosis, and in one animal by post-mortem anatomopathological examination. According to the observed, we recommend caution when large amounts of citrus pulp are used as bulky food.
\end{abstract}

KEYWORDS: sheep; Actinomyces bovis; thiamine; nutrition; ruminant.

\begin{abstract}
RESUMO: A polpa cítrica está entre os produtos que podem ser utilizados como substitutos na alimentaçáo de ruminantes, diminuindo os gastos e mantendo a qualidade nutricional do alimento fornecido aos animais, porém, esses alimentos devem ser utilizados de forma que não tragam malefícios. Assim, o presente relato visa apresentar a ocorrência de erosão dentária, actinomicose e polioencefalomalácia em ovinos criados e mantidos recebendo alimentação à base de polpa cítrica úmida despectinada na concentraçáo de $50 \%$ do volumoso. A actinomicose foi diagnosticada em cinco animais por meio de exame clínico, radiográfico e cultivo microbiológico, e após tratamento três animais foram curados. Já a polioencefalomalácia foi confirmada em dez animais pelos sintomas manifestados, eficiência da terapia instituída em nove animais e exame anatomopatológico de um animal que veio a óbito. De acordo com o observado, deve-se ter cuidado ao utilizar grande quantidade de polpa cítrica úmida como volumoso.
\end{abstract}

PALAVRAS-CHAVE: ovelhas; Actinomyces bovis; tiamina; nutrição; ruminantes.

'Faculdade de Medicina Veterinária e Zootecnia, Universidade de São Paulo (USP) - São Paulo (SP), Brazil.

${ }^{2}$ Department of Veterinary Medicine, Faculdade de Zootecnia e Engenharia de Alimentos, Universidade de São Paulo (FZEA-USP) - São Paulo (SP), Brazil.

${ }^{3}$ Faculdade de Medicina Veterinária, Universidade Federal de Uberlândia) - Uberlândia (MG), Brazil.

*Corresponding author: ehbirgel@usp.br

Received on: 03/03/2016. Accepted on: 09/01/2017 
In Brazil, there are large amounts of agroindustrial waste that can be used in animal feed to reduce production costs and to avoid environmental damage (RODRIGUES et al., 2011; CHAVES et al., 2014).

A sub-product of the orange juice industry, composed of bark, bagasse and seeds of citrus fruits that were used in the extraction of juice (PEREIRA et al., 2007; CHAVES et al., 2014) and discarded fruits (MENEGHETTI; DOMINGUES, 2008), the dry citrus pulp, has been used in Brazil to feed ruminants since 1985 (BRACARENSE et al., 1999). Citric pulp is an energetic food with a low protein content, rich in pectin and characterized as an intermediate between bulky and concentrated (PEDROSO; CARVALHO, 2005; CHAVES et al., 2014). It can be used as a partial or total substitute of corn in concentrate for growing sheep as it does not affect apparent digestibility of nutrients, animal performance (GILAVERTE et al., 2011) and does not influence carcass characteristics (RODRIGUES et al., 2008).

Due to the high costs of drying, dehydration and pelletizing of the citrus pulp, many producers started using it in its natural form (PEREIRA et al., 2008, PEGORARO et al., 2012). The dry citrus pulp have $14.82 \%$ dry matter, $6.80 \%$ crude protein, $69.29 \%$ NDF, $57.46 \%$ acid detergent fiber (ADF) and $67.7 \%$ nutrients digestibles totals (NDT) (VALADARES FILHO et al., 2015).

The present case report aims to show the possible risks associated with the excessive use of wet citrus pulp in ruminant feed and its association with tooth erosion, occurrence of actinomycosis and polioencephalomalacia.

In 2014 and 2015, sheep, crossbred Dorper with Santa Inês, from semi-intensive sheep-rearing, located in the region of Leme, in the interior of São Paulo, Brazil, were attended by the Department of Veterinary Medicine and Clinic of Small Ruminants of the Clinical-Hospital Didactic Unit (UDCH) of the Department of Veterinary Medicine of the Faculdade de Zootecnia e Engenharia de Alimentos (FZEA) of Universidade de São Paulo (USP). The animals received $50 \%$ of the dietary mass in the humid citrus pulp and 50\% in napier grass, sugar cane, corn silage or coast-cross pasture (Fig. 1). Aside from it, the animals received water and mineral salt at will.

In a large number of animals, lesions on the enamel of the incisor teeth, characterized by polishing of dental surfaces, yellowish appearance of teeth, corrosion and wear of enamel and dentin were found (Fig. 2). These alterations were found in all animal categories, except in infants or young animals in which the molt had occurred recently.

The observed lesions are similar to those described in the acid erosion in teeth of human due to chemical processes (AGUIAR et al., 2006; BRANCO et al., 2008). According to AGUIAR et al. (2006), intake of acidic foods such as citrus fruit consumption, acidic fruit juice, acid soda, sports energy drinks, carbonates and mineral replenishers can cause irreversible pathological wears to dental tissues. Any acidic substance with a $\mathrm{pH}$ less than 5.5 for dental enamel and less than 4.5 for dentin may dissolve the crystals of hydroxyapatite and cause demineralization of the surface of the enamel, which may lead to significant loss of tooth structure (BRANCO et al., 2008).

During the pectin extraction process, the orange slush is washed with water for 50 minutes, subjected to heating with steam at $60-90^{\circ} \mathrm{C}$, treated with nitric acid and then pressed. The product of this pressing is the dehydrated citrus pulp, which has very acidic $\mathrm{pH}$, around 2.4 . The acid action of the despectinated citrus pulp, ingested for a long period, determines that the dental enamel of the incisor teeth is corroded (SARTURI, 2008).

Associated with this acid erosion of the teeth, there was an increase in volume in the horizontal mandibular branch of hard consistency in five adult sheep (Fig. 3). The swelling was located between the premolar and molar teeth and affected the left mandible in $40 \%(2 / 5)$, the right mandible in $40 \%(2 / 5)$

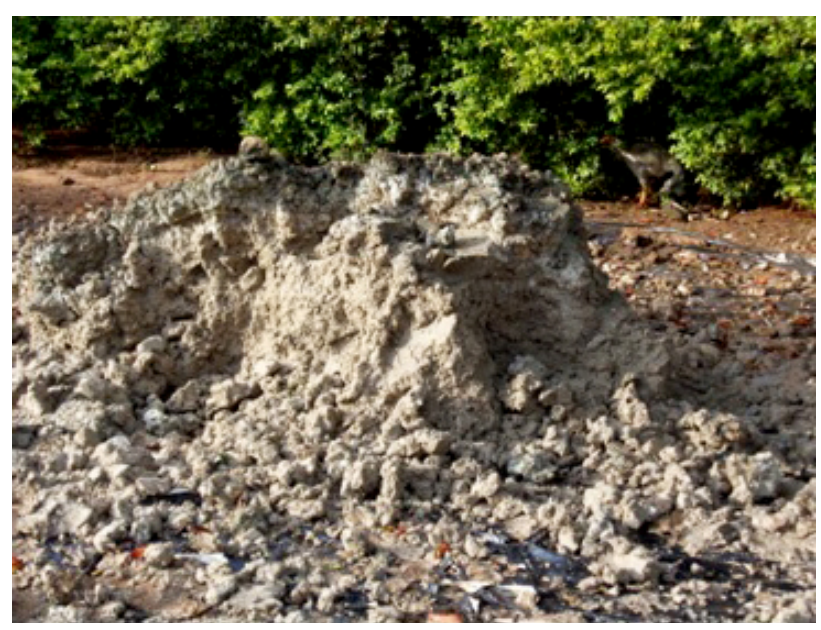

Figure 1. Appearance of the despectinated wet citrus pulp.
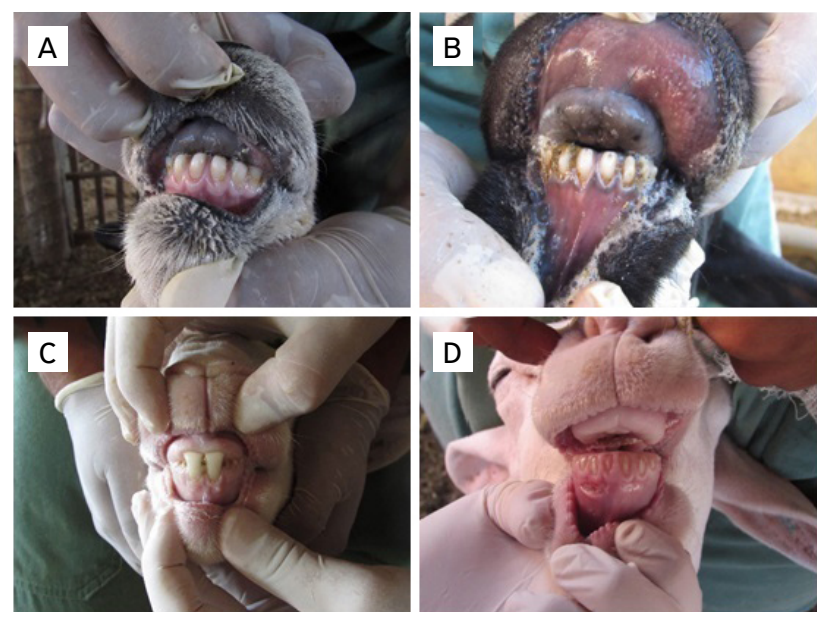

Figure 2. Erosion of incisor teeth resulting from the ingestion of despectinated wet citrus pulp: (A) polishing the incisor teeth; (B) yellowish appearance of the teeth, erosion of the enamel and retraction of the gingiva; (C) young animal, in which the tweezers were changed, with complete corrosion of the milk teeth; (D) complete corrosion of the incisor teeth. 
and in $20 \%(1 / 5)$ the two branches of the jaw. There was also slight edema occurring around the lesions in 100\% (5/5) of the animals, pain sensitivity to palpation in $20 \%(1 / 5)$, and ulceration of the skin with the presence of fistula that drained purulent secretion of creamy aspect and straw yellow coloration in $40 \%(2 / 5)$ of the affected sheep. During the aspiration puncture of the volume increases for the collection of material for the microbiological examination, it was possible to obtain yellowish, creamy, blood contaminated secretion with the presence of small and hard granules similar to the sulfur granules. The lesions presented by the animals in the mandibular region, as well as the characteristics of purulent secretion, are similar to those ones described for actinomycosis (RIET-CORREA, 2001; ALVIM; FILADELPHO, 2005; ANTUNES et al., 2012).

Radiographic findings demonstrated lesions in the region of second and third molar teeth, with bone lysis and cortical thinning. Around the lesions, there was a sclerosis area, smooth periosteal reaction and a radiolucent area, being indicative of bone loss, suggesting, as described by NIEHAUS (2009), the occurrence of osteomyelitis (Fig. 4).

The bacterial isolation was performed in blood agar medium (brain heart infusion - BHI, Difco+sterile defibrinated sheep blood, Newprov), and agar plates were incubated at $37^{\circ} \mathrm{C}$ under anaerobic conditions (ANAEROBAC, Probac) for 20 days. Gram stain showed typical diphtherial forms (non-spore-forming Gram-positive rods) of bacteria of the genus Actinomyces.

Although actinomycosis is considered rare in sheep (RIETCORREA, 2001; ANTUNES et al., 2012), it has been reported in sheep of the Rocky Mountains (Ovis canadensis canadensis) and Dall sheep (Ovis dalli dalli) a high prevalence, respectively, equal to $12.1 \%$ and $23.3 \%$ (HOEFS; BUNCH, 2001). In the

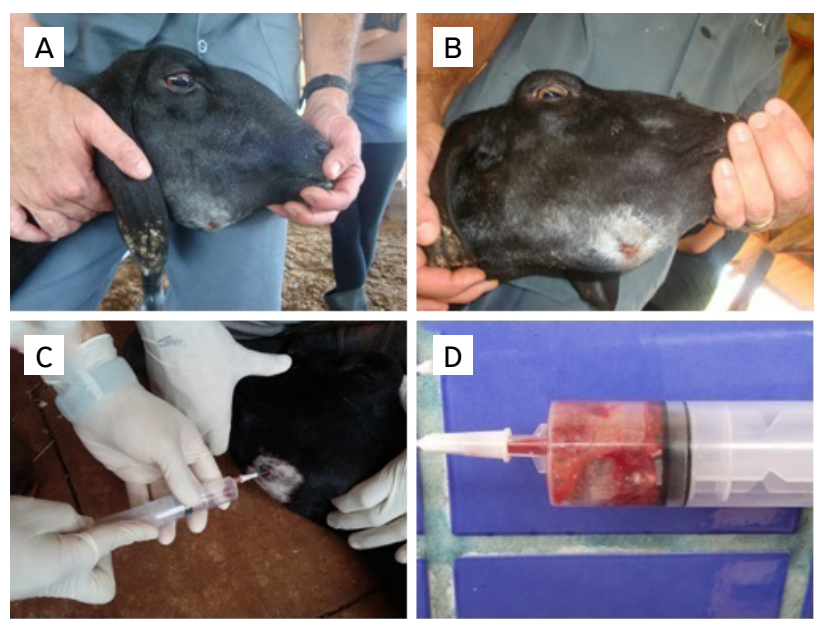

Figure 3. Actinomycosis in ovine: $(A)$ increased volume of hard consistency in the mandibular region; $(B)$ ulceration of the skin with the presence of fistula; $(C)$ puncture of the fistula to collect material for bacterial isolation; (D) yellowish purulent secretion, creamy, contaminated with blood and with the presence of small and hard granules similar to the sulfur granules. study conducted by HOEFS; BUCH (2001), it was observed that this disease did not occur in wild sheep from Eurasia, but this disease was observed in $5.0 \%$ of domestic sheep (Ovis aries) jaws examined. In sheep of the Rocky Mountains and Dall sheep, HOEFS; BUCH (2001) associated the occurrence of actinomycosis with tooth abrasion and lesions in the buccal cavity, resulting from the ingestion of a great quantity of mineral matter present in the fodder, which would facilitate the penetration of the bacterial agent. In domestic ruminants, Actinomyces bovis is a commensal bacterium of the oral cavity that only causes disease in the presence of wounds caused by coarse and pointed forages or by periodontal injury, particularly in the tooth replacement period (RIET-CORREA, 2001; ANTUNES et al., 2012).

It was observed in the property served the involvement of $2.5 \%$ of the animals of the herd $(5 / 200)$, and the predisposing factor for the penetration of the bacteria was acid erosion, tooth wear and gingival retraction due to ingestion of large amounts of moist citrus pulp.

The treatment was based on potassium iodide and antibiotic therapy (RIET-CORREA, 2001). The dosage used was $2 \mathrm{~g}$ of oral potassium iodide once daily for 10 days and 50,000 IU / kg of penicillin intramuscularly, three applications with a three day interval. ALVIM; FILADELPHO (2005) indicate the treatment through combined surgery with iodide-based medication and high doses of intravenous penicillin and streptomycin, but only in maxillary actinomycosis. Although the authors report low treatment efficacy (ALVIM; FILADELPHO, 2005;
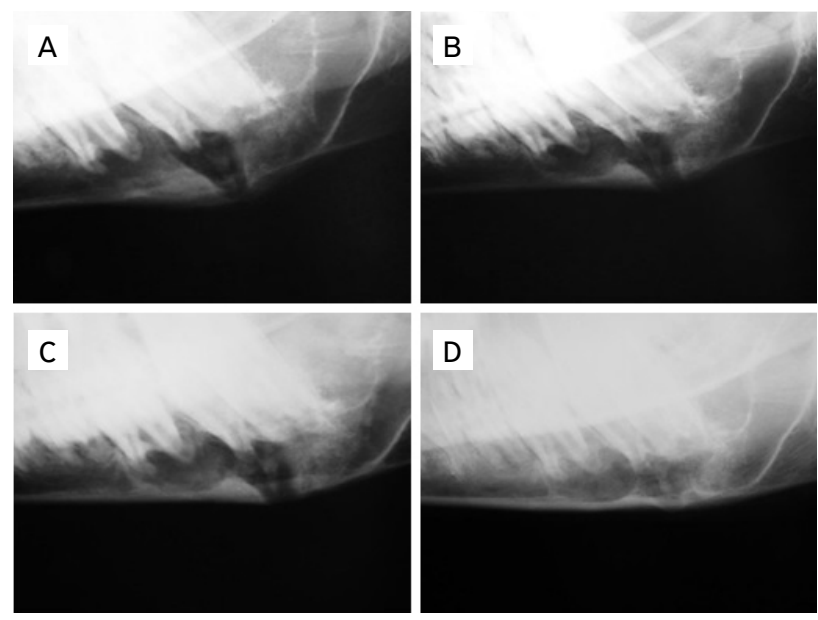

Figure 4. Radiographs of treatment evolution of the horizontal branch of the right mandible of animal of the ovine specie, identification number 389, adult, female, mixed Dorper with Santa Inês, with diagnosis of Actinomycosis. (A) It was observed in rostral region of the root of the third molar tooth lysis that extended leading to cortical discontinuity. Involving the lesion was an area of sclerosis and a smooth periosteal reaction; (B) it was observed extension of the lesion to the root of the second molar tooth; $(C)$ there was an increase in intralesional radiopacity and surrounding sclerosis; (D) the lesion was almost imperceptible with radiopacity, equating to adjacent normal bone tissue with a discrete halo of surrounding sclerosis. 
ANTUNES et al., 2012), the present report showed cure of the disease in treated animals. During radiological follow-up, radiopacity increased overlapping the lesion site, and subsequent radiographic images showed a decrease in areas of lysis and almost imperceptible cortical discontinuity, indicating a favorable remodeling compatible with cure (Fig. 4).

In this property, $25 \%(10 / 40)$ of the lambs from 5 to 7 months of age that were completely confined presented neurological disorders. These animals presented motor, opisthotonus and amaurosis incoordination, symptoms similar to those ones described in experimentally induced polioencephalomalacia in cattle (SANT'ANA et al., 2009b; NOGUEIRA et al., 2010) and in spontaneously affected animals (MENDES et al., 2007). The animals with more severe symptoms, inability to stay in the station, lateral decubitus, opisthotonus, spastic paresis of the hind limbs, pedaling episodes and death were observed.

During the necropsy, there was a yellowish aspect of the cerebral cortex, and a fragment of the brain was fluoresce when submitted to Wood's light. The histopathological evidence revealed gray matter presenting neutrophilic spongiosis, increased perineuronal and perivascular spaces and neuronal necrosis, also found by SANT'ANA et al. (2009b) and NOGUEIRA et al. (2010). Treatment of the other nine ewes with vitamin B1 (thiamine) resulted in regression of neurological symptoms and reestablishment of animal health status.

According to SANT'ANA et al. (2009a), the diagnosis of polioencephalomalacia can be made based on clinical, anatomopathological and fluorescence visualization of the affected areas of the encephalon (mainly telencephalic cortex) when exposed to ultraviolet light, and the recovery of the animals in response to treatment with thiamine allows the therapeutic diagnosis of this disease.

The occurrence of polioencephalomalacia has been associated to abrupt changes in diet and to fiber-poor diets and rich in energy concentrates that would determine indigestion in ruminants with changes in the microbial flora (NOGUEIRA et al., 2010; MAS et al., 2010; MENDONÇA JUNIOR et al., 2010).

The wet citrus pulp has a high content of soluble carbohydrates and is potentially a producer of lactic acid, which in turn can lower the ruminal $\mathrm{pH}$ (physiological range of about 5.5 to 7.0) (PINZON; WING, 1976; TEIXEIRA et al., 2009). Due to its very acidic $\mathrm{pH}$, this acidity can unbalance the ruminal microbiota, inhibiting the thiamine-producing microorganisms and favoring the growth of thiaminase producers (MENDONÇA JUNIOR et al., 2010), thus predisposing to polioencephalomalacia (SAMPAIO et al., 2015). It is the case in animals with excessive concentrate consumption, so rumen $\mathrm{pH}$ decreases leading to alteration in thiamine metabolism (MAS et al., 2010; CUNHA et al., 2011).

Although it provides a satisfactory cost-benefit ratio, diets that offer excess wet citrus pulp must be rethought in order to avoid future complications.

| | | | | | | | | | | | | | | | | | | | | | | | | | | | | | | | | | | | | | | | | | | | | | | | | | | | | | | | | | | | | | | | | | | | | | | | | | | | | | | | | | | | | | | | | | | | | | | | | | | | | | | | | | | | | | | | | | | | | | | | | | | | | | | | | | | | | | | | | | | | | | | | | | | | | | | | | | | | | | | | | | | | | | | | | | | | | | | | | | | | | | | | | | | | | | | | | | | | | | | | | | | | | | REFERENCES

AGUIAR, F.H.B.; GIOVANI, E.M.; MONTEIRO, F.H.L.; VILLALBA, H.; SOUSA, R.S.; MELLO, J.A.J.; TORTAMANO, M. Erosão dental definição, etiologia e classificação. Revista do Instituto de Ciências da Saúde, v.24, n.1, p.47-51, 2006.

ALVIM, N.C.; FILADELPHO, A.L. Actinomicose em bovino da raça Limousin: relato de caso). Revista Científica Eletrônica de Medicina Veterinária, 2005.

ANTUNES, J.M.A.P.; ALMEIDA, A.C.S.; RIBEIRO, M.G.; AMORIM, R.L.; HUSSNI, C.A.; LISTONI, F.J.P.; MEGID, J. Actinomicose mandibular em ovino: relato de caso. Arquivos do Instituto Biológico, v.79, n.3, p.405-409, 2012.

BRACARENSE, A.P.F.R.L.; FARIA DOS REIS, A.C.; NETTO, D.P.; ALFIERI, A.A. Enterite necrótica e hemorrágica em bovinos leiteiros na região de Londrina-PR, alimentados com polpa cítrica. In: ENCONTRO NACIONAL DE PATOLOGIA VETERINÁRIA, 9., Belo Horizonte, 1999. Anais... 1999. p. 127.

BRANCO, C.A.; VALDIVIA, A.D.C.M.; SOARES, P.B.F.; FONSECA, R.B.; FERNANDES NETO, A.J.; SOARES, C.J. Erosão dental: diagnóstico e tratamento. Revista de Odontologia da UNESP, v.37, n.3, p.235-242, 2008.
CHAVES, B.W.; STEFANELLO, F.S.; BURIN, A.P.; RITT, L.A.; NORNBERG, J.L. Utilização de resíduos industriais na dieta de bovinos leiteiros. Revista Eletronica em Gestão, Educação e Tecnologia Ambiental, v. 18, p. 150-156, 2014.

CUNHA, P.H.J.; BADIAL, P.R.; CAGNINI, D.Q.; OLIVEIRA-FILHO, J.P.; MORAES, L.F.; TAKAHIRA, R.K.; AMORIM, R.L.; BORGES, A.S. Poliencefalomalacia experimental em bovinos induzida por toxicose por enxofre. Pesquisa Veterinária Brasileira, v.31, n.1, p.41-52, 2011 .

GILAVERTE, S.; SUSIN, S.G.I.; PIRES, A.V.; FERREIRA, E.M.; MENDES, C.Q.; GENTIL, R.S.; BIEHL, M.V.; RODRIGUES, G.H. Digestibilidade da dieta, parâmetros ruminais e desempenho de ovinos Santa Inês alimentados com polpa cítrica peletizada e resíduo úmido de cervejaria. Revista Brasileira de Zootecnia, v.40, n.3, p.639-647, 2011.

HOEFS, M.; BUNCH, T.D. Lumpy jaw in wild sheep and its evolutionary Implications. Journal of Wildlife Diseases, v.37, n. 1, p.39-48, 2001.

MAS, A.; SANES, J.M.; TRIGUEROS, I.; PALLARÉS, F.J.; SEVA, J.I. Poliencefalomalacia asociada a acidosis metabolica en bovino de Lidia. Anales de Veterinaria de Murcia, v.26, p.91-96, 2010. 
MENDES, L.C.N.; BORGES, A.S.; PEIRÓ, J.R.; FEITOSA, F.L.F.; ANHENSINI, C.R. Estudo retrospectivo de 19 casos de polioencefalomalácia, em bovinos, responsivos ao tratamento com tiamina. Arquivo Brasileiro de Medicina Veterinária e Zootecnia, v.59, n. 1, p.239-241, 2007.

MENDONÇA JUNIOR, A.F.; BRAGA, A.P.; RODRIGUES, A.P.M.S.; SALES, L.E.M. Vitaminas: uma abordagem pratica de uso na alimentação de ruminantes. Agropecuária Científica no SemiÁrido, v.6, n.4, p.1-16, 2010.

MENEGHETTI, C.C.; DOMINGUES, J.L. Características nutricionais e uso de subprodutos da agroindústria na alimentação de bovinos. Revista Eletrônica Nutritime, v.5, n.2, p.512-536, 2008.

NIEHAUS, A. Dental disease in llamas and alpacas. Veterinary Clinics of North America: Food Animal Practice, v.25, p.281-293, 2009.

NOGUEIRA, A.P.A.; SOUZA, R.I.C.; SANTOS, B.S.; PINTO, A.P.; RIBAS, N.L.K.S.; LEMOS, R.A.A.; SANT'ANA, F.J.F. Polioencefalomalacia experimental induzida por amprólio em bovinos. Pesquisa Veterinária Brasileira, v.30, n.8, p.631-636, 2010.

PEDROSO, A.M.; CARVALHO, M.P. Polpa cítrica e farelo de glúten de milho. In: PEDROSO, A.M. Subprodutos para ruminantes: estratégias para reduzir o custo de alimentação. Piracicaba: AgriPoint, 2005. v.2. p.1-35.

PEGORARO, J.; SALEM, N.F.M.; SANTOS, J.M.G.; ANDREAZZI, M.A. Uso do bagaço da laranja na alimentação animal. In: MOSTRA INTERNA DE TRABALHOS DE INICIAÇÃO CIENTÍFICA, 6., 2012. Anais... Maringá: Centro Universitário de Maringá, 2012.

PEREIRA, M.S.; RIBEIRO, E.L.A.; MIZUBUTI, I.Y.; ROCHA, M.A.; KURAOKA, J.T.; NAKAGHI, Y.O. Consumo de nutrientes e desempenho de cordeiros em confinamento alimentados com dietas com polpa cítrica úmida prensada em substituição à silagem de milho. Revista Brasileira de Zootecnia, v.37, n. 1, p.134-139, 2008.

PEREIRA, M.S.; RIBEIRO, E.L.A.; MIZUBUTI, I.Y.; TURINI, T.; NORO, L.Y.; PINTO, A.P. Carcaça e não-componentes da carcaça de cordeiros recebendo polpa cítrica úmida prensada em substituição à silagem de milho. Acta Scientarium Animal Sciences, v.29, n. 1, p.57-62, 2007.

PINZON, F.J.; WING, J. Effects of citrus pulp in high urea rations for steers. Journal of Dairy Science, v.59, p. 1 100-1 103, 1976.
RIET-CORREA, F. Actinomicose. In: Doenças de ruminantes e equinos. 2. ed. São Paulo: Varela, 2001. v.1. 423p.

RODRIGUES, G.H.; SUSIN, I.; PIRES, A.V.; MENDES, C.Q.; URANO, F.S.; CASTILLO, C.J.C. Polpa cítrica em rações para cordeiros em confinamento: características da carcaça e qualidade da carne. Revista Brasileira de Zootecnia, v.37, n. 10, p. 1869-1875, 2008.

RODRIGUES, G.H.; SUSIN, I.; PIRES, A.V.; NUSSIO, L.G.; GENTIL, R.S.; FERREIRA, E.M. Desempenho, características da carcaça, digestibilidade aparente dos nutrientes, metabolismo de nitrogênio e parâmetros ruminais de cordeiros alimentados com rações contendo polpa cítrica úmida semidespectinada e/ou polpa cítrica desidratada. Revista Brasileira de Zootecnia, v.40, n. 10 , p.2252-2261, 2011.

SAMPAIO, P.H.; FIDELIS JUNIOR, O.L.; MARQUES, L.C.; CADIOLI, F.A. Polioencefalomalacia em Ruminantes. Investigação, v.14, n.2, p.96-103, 2015.

SANT'ANA, F.J.F.; LEMOS, R.A.A.; NOGUEIRA, A.P.A.; TOGNI, M.; TESSELE, B.; BARROS, C.S.L. Polioencefalomalacia em ruminantes. Pesquisa Veterinária Brasileira, v.29, n.9, p.681-694, 2009a.

SANT'ANA, F.J.F.; RISSI, D.R.; LUCENA, R.B.; LEMOS, R.A.A.; NOGUEIRA, A.P.A.; BARROS, C.S.L. Polioencefalomalacia em bovinos: epidemiologia, sinais clínicos e distribuição das lesões no encéfalo. Pesquisa Veterinária Brasileira, v.29, n.7, p.487-497, 2009b.

SARTURI, J.O. Polpa cítrica úmida despectinada em substituição à polpa peletizada no desempenho de bovinos de corte confinados. 2008. 133p. Dissertation (Mestrado) - Escola Superior de Agricultura "Luiz de Queiroz", 2008.

TEIXEIRA, A.M.; GONÇALVES, L.C.; VELASCO, F.O.; RIBEIRO JÚNIOR, G.O.; MAGALHÃES, F.A. Polpa cítrica na alimentação de bovinos de leite. In: GONÇALVES, L.C.; BORGES, I.; FERREIRA, P.D.S. Alimentos para gado de leite. Belo Horizonte: FEPMVZ, 2009. 576p.

VALADARES FILHO, S.C.; MACHADO, P.A.S.; CHIZZOTTI, M.L.; AMARAL, H.F.; MAGALHÃES, K.A.; ROCHA JUNIOR, V.R.; CAPELLE, E.R. CQBAL 3.0. Tabelas Brasileiras de Composição de Alimentos para Bovinos. 2015. Available from: <http://cqbal.agropecuaria. ws/webcqbal/index.php>. Accessed on: Jan. 3, 2016. 